under the special guidance of Prof. Verneau, by whom the greater part of its exploration had been carried out. As is well known, this cave yielded several human skeletons, all of the Cro-Magnon type, the most deeply interred lying in association with bones of the reindeer. Several of these have been left in situ preserved under glass; while in a small museum erected, close by the mouth of the grotto, at the expense of Sir Thomas Hanbury, are arranged the bones and other objects discovered in it. After a hasty visit to the Grotte du Cavilion the congressionists proceeded to inspect the famous Grotte des Enfants under the same excellent guidance. The two celebrated skeletons from the lowest foyer of this cave, the types of Verneau's negroid Race Grimaldi, are safely preserved in the Monaco Museum. These discourses sub divo were necessarily succinct, but they were supplemented by fuller addresses of extreme interest during the following forenoon by the Abbé de Villeneuve, Profs. Boule and Verneau, and $M$. Cartailhac, under whose joint authorship a beautifully illustrated volume on the results of their exploration of these caves will shortly be published by the generous provision of the Prince of Monaco.

The next day's programme was reserved specially for papers on the engravings and frescoes on the walls of prehistoric caverns. The Abbé Breuil presented a communication on the process of the evolution of art during the Reindeer age, a résumé of a large work on which he is engaged, resulting from his laborious copying of the wall pictures of many caverns in collaboration with his colleagues Cartailhac, Capitan, Peyrony, and Bourrinet. The most important as well as most attractive item, however, was the exhibition by Dr. Capitan of a long series of lantern-slides of mural, engraved, and polychrome picturesthe latter in colour-most carefully copied by himself, the Abbé Breuil, and their associates named above, under the most trying and difficult conditions in the grottoes-more frequently than not far in their dark, damp, and cramped recesses--of Mas-d'Azil, Combarelles, Marsoulas, Bernifal, Les Eyzes, de Freye (Dordogne), la Mouthe, Altamira, Font de Gaume, de Teyjat, La Greze, and others. The number and variety of subjects depicted indicates powers of accurate observation and a mastery of hand in the arts of sculpture and drawing at that early age which are really astonishing, and it is evident that this wonderful capacity for art was the common heritage of Palæolithic man in all parts of Europe. Rhinoceros merckii and some dozen other extinct quadrupeds appear to have been his favourite studies. Bison priscus, however, was the species most frequently and most characteristically represented, being perhaps the commonest or the most dreaded member of his fauna. The human figure was less frequently, and always rudely, portrayed, and usually with monstrous or grotesque faces, suggesting that actors in some ceremonial were intended to be depicted in masks, recalling the dance-masks of the Chiriqui and Arizona Indians. Further papers on the same theme occupied also a great part of the following morning's sitting, at which the most interesting exhibition was a series of burins and scrapers of flint from the Grotto of Eyzes, exquisitely manufactured of every degree of fineness-some of them worked at both ends-to serve the manifold purposes of the artist. They were unquestionably the very tools by which the wall pictures beside them had been executed. With the exception of a short note by Dr. Arthur Evans (who on rising was very warmly greeted by the congress), on the Egean, Minoan, and Mycenæan epochs, the remainder of the communications on the day's programme dealt with the Bronze and Iron age in Europe.

The sitting of the forenoon of Saturday, April 2I, was given up chiefly to the archæology of northern Africa. The most important communication was M. Flammaud's, on his discovery in the Sahara of megalithic monuments of new shapes and of peculiar sculpture, and on the numerous evidences he had obtained of contact between the interior of Lybia and Egypt in the Neolithic age. The afternoon was spent on an excursion through beautiful scenery viâ the well-known Tropaea Augusti at La Turbie to the mysterious prehistoric entrenchments occupying the summit of Mont Bastide, as that of many of the other foot-hills of the Maritime Alps. The congress assembled on Sunday afternoon for the formal closing ceremonies usual on such occasions, the Prince of Monaco being again represented by his son, who, at the palace previous to the meeting, had, on his father's behalf, conferred the decoration of St. Charles on the presidents, the secretaries, and several of its more distinguished members, of whom Sir John Evans received the cross and ribbon of the Order.

Several social entertainments were given during the week " en 1'honneur des congressistes," including, besides a reception at the palace, an evening performance of Méphistofèles and a matinée concert, both in the beautiful Casino Theatre.

For those--and they proved a goodly company-who could spare the time, a whole-day excursion, under the able leadership of M. Paul Goby, to the prehistoric monuments-dolmens, tumuli, and entrenchments-in the neighbourhood of Grasse was arranged by the excellent committee of organisation as a pleasant termination to a very successful and profitable session of the congress.

\section{SUMMER TEMPERATURES OF THE NORTH SEA.}

THE "Bulletin Trimestriel " of the International Council for the Exploration of the Sea, for the period July to September, 1905, has just been issued. As the observations are for the summer months, they are naturally more numerous than in other seasons of the year, and an immense amount of material is dealt with. The increase in the number of surface observations, and the extension of the area from which they have been obtained, are specially noteworthy; a plate of nine charts showing the variations of mean temperature in the North Sea for tenday periods, from July I to September 30 , I905, is added to the usual quarterly maps. These charts have been prepared by dividing the area into squares of $1^{\circ}$, and $\frac{1}{2}^{\circ}$ close to the coast, and the results checked by mean values from Dutch observations, worked up by a different method.

The sections drawn from the observations of the special steamers sent out by the different countries are very numerous in the narrower seas, forming a close network in the Baltic and the North Sea. A line north-eastward from Scotland defines the conditions across the northern entrance to the North Sea, but it is unfortunate that, except for some very useful lines running seaward from the coast of Ireland, and one section from Iceland to Færöe, information from the western section of the area is somewhat deficient, notably in the Færöe-Shetland Channel. It would be a great matter if observations in the depth could be carried further seaward to the southwest of the British Isles with the view of ascertaining the precise limit to which waters of Mediterranean origin penetrate northward, and in this connection an increase in the number of gas samples analysed would be of value.

\section{UNIVERSITY AND EDUCATIONAL INTELLIGENCE.}

OXFORD.-The following is the text of the speech delivered by Prof. Love in presenting Prof. J. Milne for the degree of D.Sc. honoris causa at the Encaenia on June $20:-$

In terrae motibus cognoscendis nemini profecto cedit Ioannes Milne. Hic ille est qui nova eademque plurima quaerendi instrumenta commentatus, quibus vim terrae motuum longinquis in locis redundantem emetiretur, ostendit tribus quibusdam momentis rem agi : duobus enim tremoribus medium terrae globum concutientibus succedere tertium latius patentem et in summo volitantem, sicut undam mare supereminentem. His repertis illud etiam consecutus est ut interioris terrae naturam et compagem certius cognosceret. Nullas profecto regiones non peragravit vir acerrimus, dum telluris superficiei studet, praecipuam vero laudem adeptus est quod rei publicae Iaponicae viginti annos inservit, Geologiae doctor insignis, fodinarum publicarum curator peritissimus. Ibi etiam sexcentas stationes disposuit omnia quae ad terrae motus pertinent et observantium et litteris mandantium. His etiam diebus patriae redditus in insula Vecti tale labor-

No. I 913 , VOI. 74] 